\title{
Optimized microwave reflux extraction and antioxidant activities of piperine from black and white piper nigrum
}

Olalere Olusegun Abayomi", Abdurahman Hamid Nour, Alara Oluwaseun Ruth,Omar Abed Habeeb

Faculty of Chemical Engineering and Natural Resources, Universiti Malaysia Pahang (UMP), Lebuhraya Tun Razak26300, Malaysia. Article Info: Submitted on March 20, 2017, Accepted on June 20, 2017.

\begin{abstract}
In this study, the microwave reflux technique was employed to extract piperine from black and white pepper. This is due to its ability to combine the microwave and the conventional solvent extraction together with a high degree of selectivity and quality extract. The extraction process was optimized using the $\mathrm{L}_{9}$-Taguchi experimental design. This investigated the effects of four independent factors (irradiation time $\left(\mathrm{x}_{1}\right)$, microwave power level $\left(\mathrm{x}_{2}\right)$, feed particle size $\left(\mathrm{x}_{3}\right)$ and molar ratio $\left.\left(\mathrm{x}_{4}\right)\right)$ on piperine yield. Antioxidant activity of the oleoresin extracts were later evaluated using DPPH (1, 1-diphenyl-1-picrylhydrazyl) radical scavenging assay. The optimum extraction condition in black pepper refluxation was attained at 90 min irradiation time $\left(\mathrm{x}_{1}\right), 350 \mathrm{~W}$ power level $\left(\mathrm{x}_{2}\right), 0.105 \mathrm{~mm}$ feed particle size $\left(\mathrm{x}_{3}\right)$ and $10 \mathrm{~mL} / \mathrm{g}$ molar ratio $\left(\mathrm{x}_{4}\right)$ with an extremum ranking in decreasing order of $\mathrm{x}_{3}>\mathrm{x}_{4}>\mathrm{x}_{2}>\mathrm{x}_{1}$. However,from the white pepper refluxation an optimum condition was achieved at $120 \mathrm{~min}$ irradiation time $\left(\mathrm{x}_{1}\right), 350 \mathrm{~W}$ power level $\left(\mathrm{x}_{2}\right), 0.300 \mathrm{~mm}$ feed particle size $\left(\mathrm{x}_{3}\right)$ and $6 \mathrm{~mL} / \mathrm{g}$ molar ratio $\left(\mathrm{x}_{4}\right)$ with a corresponding decreasing extremum order of $\mathrm{x}_{1}>\mathrm{x}_{4}>\mathrm{x}_{2}>\mathrm{x}_{3}$. From the results obtained from concentrationdependent radicals scavenging activity it was concluded that white oleoresins extract were much higher in inhibitory activity than that of black oleoresin extract.
\end{abstract}

Keywords: Microwave reflux extraction; Taguchi optimization DPPH radical scavenging activities; Piperine; Piper nigrum.

\section{Introduction}

Black and white peppers are tropical crops of piperaceae family with over a thousand species usually produced using the seed of the plant from the freshly plucked spice berries ${ }^{1}$. The major difference between both species is that the fruit of white pepper is allowed to matured completely after which it is soaked in water for some time ${ }^{2}$. The outer layer is scratched off consequent to the mollification of fresh fruit to form a creamy white piper nigrum $^{3}$.Black piper nigrum on the other hand is produce by drying an unripe fruits to form a black reticulated seed as shown in Figure.1.

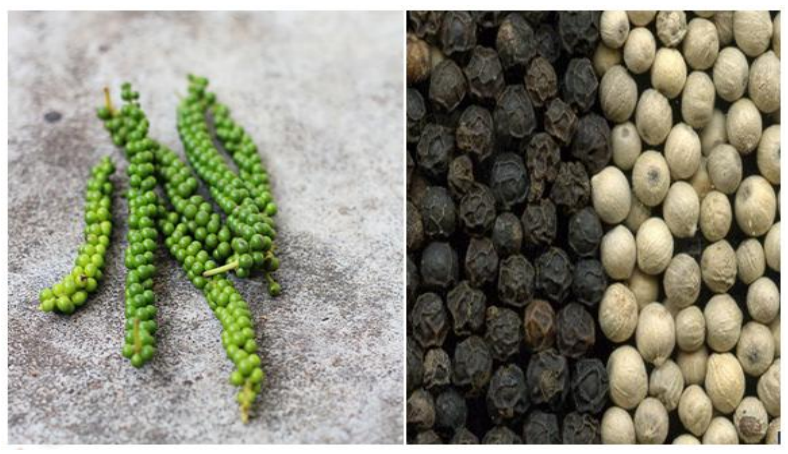

Figure 1: Green and matured Piper nigrum seeds.

Piperine is the major active alkaloids in black and white piper nigrumwithcharacteristicantiinflammatory, anticancer,antipyretic, analgesic, antitumor, anti-depressant, and antioxidant properties ${ }^{4}$.
It is an important component responsible for the pungency in piper nigrum. It is slightly soluble in water and these increases at elevated temperatures. Many researches had investigated the nutraceutical and medicinal nature of white and black pepper due to the presence of bioactive-piperine ${ }^{4,5,6}$. Abdurahman ${ }^{7}$ opined that the variability in Piperine and capsaicicoids content in different cultivars of pepper is determined by variety, climate, geographical location, maturity, and the method of processing. However, the classical microwave refluxation is comparatively useful in the isolation of bioactive-alkaloids from different species of piper nigrum. It is such a method with an higher selectivity, lower solvent consumption, environmentally friendly and shorter irradiation time ${ }^{8}$. This is achieved by a selectively localized heating of the extracting solvent making it suitable for matrix with plant origin 9 . The ability of microwave reflux to isolate and extract targeted compounds from plant matrix is therefore due to the ionic conduction and dipole interaction of the electric and magnetic field ${ }^{10}$. The presence of antioxidants inside piper nigrum matrix offers remarkable advances in the treatment of some life-threatening free radical disorder such as cancer, cardiovascular diseases and neurological disorders. This has drawn the attention of researchers to focus on unveiling the therapeutic and free radical scavenging potentials of black and white piper nigrum.This research therefore investigated the 


\section{Chemical Engineering Research Bulletin 19(2017) 139-144}

optimal conditions for the extraction of essential bioactive piperine and compared the radical scavenging activities for both cultivars of piper nigrum under different extraction conditions.

\section{Materials and Methods}

\section{Materials and reagents}

A standard grade black and white piper nigrum were obtained from the Malaysian Pepper Board (MPB) located in Sarawak Malaysia at initial moisture of 34\%.Moreover, an analytical-grade ethanol, acetone, and water were obtained from the Chemical Laboratory, Universiti Malaysia Pahang, Malaysia. The DPPH (1,1-diphenyl-2-picrylhydrazyl) reagent was supplied by Sigma Aldrich Chemical Co.

\section{Sample and reagents preparation}

The two pepper samples were pulverized into a finely defined powder using eppendorf grinder(200- model Hamburg, Germany) and then kept in an airtight container. The powdered samples were clarified into five different sizes of $0.105 \mathrm{~mm}, 0.154 \mathrm{~mm}, 0.300 \mathrm{~mm}$, $0.450 \mathrm{~mm}$ and $0.900 \mathrm{~mm}$.Furthermore, a $0.0238 \mathrm{~g}$ dark purple crystalline solid of DPPH was dissolved in 95\% distilled ethanol to make up a final volume $100 \mathrm{ml}$ of $0.6 \mathrm{mM}$ DPPH stock solution.

\section{Robust experimental design}

This is an experimental design methodology which permits a higher level of consistent uniformity in the extraction parameters involving minimum number of experimental runs. This leads to a reduction in extraction time and cost of the sample used ${ }^{11}$.Taguchi optimization design also allows for an independent analysis of each extraction factor with an admittance that not all the control variables with higher variation can be controlled in actual practice ${ }^{12}$.

Table 1: Extraction Factors and operating levels.

\begin{tabular}{|c|c|c|c|c|c|c|}
\hline \multirow{2}{*}{$\begin{array}{l}\text { Extraction } \\
\text { factors }\end{array}$} & \multicolumn{3}{|c|}{ Black piper nigrum } & \multicolumn{3}{|c|}{ White piper nigrum } \\
\hline & -1 & 0 & +1 & -1 & 0 & +1 \\
\hline $\begin{array}{c}\text { Irradiation } \\
\text { Time }\left(\mathrm{x}_{1}\right)\end{array}$ & 30 & 60 & 90 & 60 & 90 & 120 \\
\hline $\begin{array}{c}\text { Microwave } \\
\text { Power } \\
\text { Level }\left(\mathrm{x}_{2}\right)\end{array}$ & 300 & 350 & 400 & 250 & 300 & 350 \\
\hline $\begin{array}{c}\text { Feed } \\
\text { Particle } \\
\text { Size }\left(\mathrm{x}_{3}\right)\end{array}$ & 0.105 & 0.154 & 0.300 & 0.105 & 0.154 & 0.300 \\
\hline $\begin{array}{c}\text { Molar } \\
\text { Ratio }\left(\mathrm{x}_{4}\right)\end{array}$ & 30 & 60 & 90 & 6 & 8 & 10 \\
\hline
\end{tabular}

The extraction factors considered for this were irradiation time $\left(\mathrm{x}_{1}\right)$, microwave power level $\left(\mathrm{x}_{2}\right)$, feed particle size $\left(\mathrm{x}_{3}\right)$, and molar ratio $\left(\mathrm{x}_{4}\right)$.The search for an optimal yield from the two samples were achieved using a three-level orthogonal design of these factors ${ }^{13}$. The factors and levels for the orthogonal design designated with $\mathrm{x}_{1}, \mathrm{x}_{2}, \mathrm{x}_{3}$, and $\mathrm{x}_{4}$ as presented in Table 1. This was analyzed using Minitab $17 \AA$ experimental design software ${ }^{14}$.

\section{Microwave reflux extraction}

A $5 \mathrm{~g}$ of piper nigrum powder sample was mixed and hydrated with distilled water. The purpose of hydrating the sample was to allow for homogeneity in the mixture. This was then loaded into the microwave reactor as illustrated in the schematic diagram (Fig.2) and irradiated in accordance with the operating conditions generated from the Taguchi experimental array.

Moreover, the microwave oven was operated in-step with the aid of 'easy-control' software, programmed for 3-level control of the microwave power, irradiation time, and temperature. The supernatant solution was thereafter filtered using the $0.45 \mu \mathrm{m}$ PTFE micro filter for subsequent spectroscopy quantification.

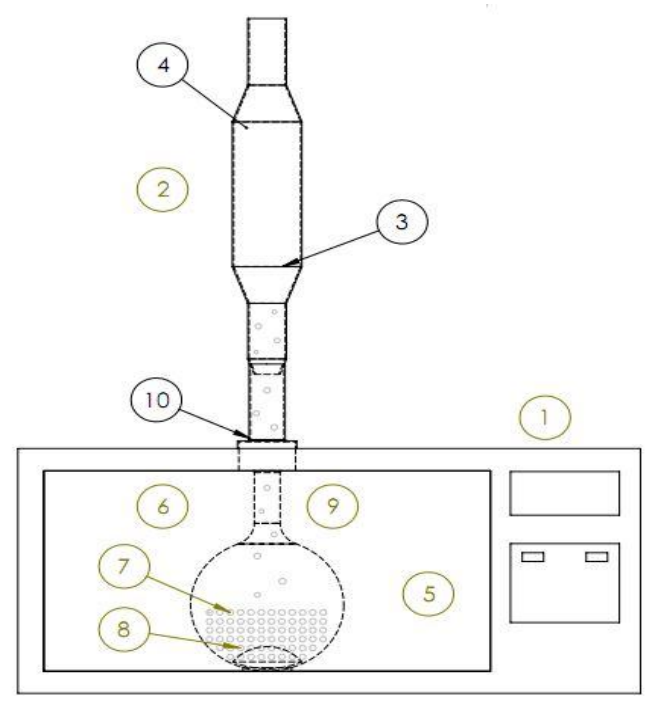

Figure 2: Schematic diagram of microwave experimental set-up. 1. Microwave oven, 2. Reflux system, 3. Ice water inlet, 4. Ice water outlet,

\section{Spectrometry quantification}

The components of the spice extract were obtained from peak area fragmentation fingerprints using a computer controlled GC-MS system, with the retention time indices and mass spectra matching as the basis for component identification ${ }^{15}$. An Agilent GCMS(5973N-Agilent Technologies, Wilmington, DE, USA)) with $30 \mathrm{~mm}$ column diameter, $0.25 \mathrm{~mm}$ internal diameter, and $0.25 \mathrm{~mm}$ film thicknesses was employed 


\section{Chemical Engineering Research Bulletin 19(2017) 139-144}

to detect and determine the quantity of the piperine present. The column oven was firstly set to $50^{\circ} \mathrm{C}$ for 5 min and then progressively increased to $125^{\circ} \mathrm{C}$ at $3^{\circ} \mathrm{C}$ per unit time, with a final $5 \mathrm{~min}$ of heating at $300^{\circ} \mathrm{C}$. The test was carried out by diluting a micro-filtered extract with an analytical standard grade acetone at ratio $1: 10.1 \mu \mathrm{L}$. This was then injected into the GCMS for components detection and quantification. The actual percentage of piperine was then calculated using the normalization techniques in relation to the quantity of the sample loading as shown in the equation below:

Piperine yield $(w / w \%)=\frac{C_{\text {content }}}{W_{\text {feed }}} 100 \%$

where, $C_{\text {content }}$ and $\mathrm{W}_{\text {feed }}$ are the amount piperine $(\mathrm{g})$ and weight of dried $(\mathrm{g})$ samples respectively.

The component spectrometry identification was carried out in triplicates using the same GC-Mass spectrometric conditions. The validity of piperine yield was determined by the standard deviation errors (SD) given in the equation below. This accounted for the deviation inherent in the repeated use of the GC-MS.

$$
\text { Standard deviation }=\sqrt{\frac{\sum\left(\mathrm{y}_{1}-y_{0}\right)^{2}}{N-1}}
$$

\section{DPPH free radical scavenging assay}

The radical-scavenging assay is a biological activity test for evaluating the antioxidant potential of the extracts obtained from natural products. The choice of DPPH reagent for this study was due to its rapid and high sensitivity in the detection of a small variation in antioxidant activities in addition to the minimal use of test samples ${ }^{18}$. This assay was conducted to compare the antioxidant capacity of spice oleoresin extracts from black and white piper nigrum.

The antioxidants properties of the spice oleoresins is therefore a function of their free radical inhibition percents ${ }^{19}$. Radical-scavenging activity of spice extracts against stable the DPPH-solution was determined using spectrophotometer set at $517 \mathrm{~nm}$ and the antioxidant activities was measured as the absorbance decreases. The method used by ${ }^{20}$ for DPPH free radical scavenging was employed in this study. The negative control $\left(\mathrm{A}_{0}\right)$ was prepared by mixing $0.5 \mathrm{ml}$ of ethanol with $2.5 \mathrm{ml}$ of the DPPH solution and absorbance was measured after $30 \mathrm{~min}$ of keeping the mixture in the dark at $25^{\circ} \mathrm{C}$.Five different concentrations of $50 \mu \mathrm{g} / \mathrm{mL}, 100 \mu \mathrm{g} / \mathrm{mL}, 150 \mu \mathrm{g} / \mathrm{mL}$, $200 \mu \mathrm{g} / \mathrm{mL}$ and $250 \mu \mathrm{g} / \mathrm{mL}$ at the optimal yield of the spice oleoresin extracts were prepared. Absorbance $\left(\mathrm{A}_{1}\right)$ was measured for a mixture of $0.5 \mathrm{ml}$ different concentration of spice oleoresin consecutively taken and mixed with $2.5 \mathrm{ml}$ of DPPH. However, in order to eliminate the colour effect of the spice extract, an absorbance denoted by $\mathrm{A}_{2}$ was taken and this comprises a mixture of the spice extracts (different concentration) and $2.5 \mathrm{ml}$ ethanol. All analysis was performed in triplicates and the average value was used to estimate the inhibition percent. The percentage inhibition was calculated using the expression below:

$$
\text { Piperine yield }(w / w \%)=\left(1-\left[\frac{A 1-A 2}{A 0}\right]\right) \times 100
$$

The percentage inhibition was plotted against the five concentrations $(50-250 \mu \mathrm{g} / \mathrm{mL})$ of the spice oleoresins extract to obtain a standard inhibition curve. The results were obtained by linear regression analysis, thereby generating a straight-line equation as shown in below:

$$
I=m c+k
$$

where $I=$ Inhibition Percent, $\quad \mathrm{c}=$ spice oleoresin concentration, $\mathrm{m}=$ slope and $\mathrm{k}=$ intercept. The $\mathrm{IC}_{50}$ value was thereafter estimated to determine the inhibition concentration of the spice oleoresin extract required to scavenge $50 \%$ of the DPPH radicals.

\section{Results and Discussion}

\section{Determination of the optimized conditions}

From design matrix in Table 2, the optimum extraction conditions for the black pepper ( $\mathrm{y}$ black) refluxation were attained at 90 min irradiation time $\left(\mathrm{x}_{1}\right), 350 \mathrm{~W}$ power level $\left(\mathrm{x}_{2}\right), 0.105 \mathrm{~mm}$ feed particle size $\left(\mathrm{x}_{3}\right)$ and $10 \mathrm{~mL} / \mathrm{g}$ molar ratio $\left(\mathrm{x}_{4}\right)$. The main effects of the four extraction variables involved in black pepper microwave refluxation decreases in the order $x_{3}>x_{4}>$ $\mathrm{x}_{2}>\mathrm{x}_{1}$ in accordance with the extremum difference.

Moreover, optimum conditions for white pepper (y white) microwave-refluxation were reached at $120 \mathrm{~min}$ irradiation time $\left(\mathrm{x}_{1}\right), 350 \mathrm{~W}$ power level $\left(\mathrm{x}_{2}\right), 0.300$ $\mathrm{mm}$ feed particle size $\left(\mathrm{x}_{3}\right)$ and $6 \mathrm{~mL} / \mathrm{g}$ molar ratio $\left(\mathrm{x}_{4}\right)$.The extraction yield of the bioactive-Piperine under the optimum conditions for black and white pepper refluxation were $2.0586 \mathrm{w} / \mathrm{w} \%$ and 4.276 $\mathrm{w} / \mathrm{w} \%$ respectively. Hence the descending order of significance of the main effects in white pepper refluxation is given by $x_{1}>x_{4}>x_{2}>x_{3}$ with respect to their extremum difference. The descending order of significance was arrived at from the delta values $(X)$ generated by Minitab $17 \AA$ software. In Taguchi designs, delta is the difference between the maximum and minimum mean response across levels of a factor. Triplicate parallel tests were conducted under the optimal response setting from the orthogonal parametric design. 


\section{Chemical Engineering Research Bulletin 19(2017) 139-144}

Table 2: $\mathrm{L}_{9}\left(3^{\wedge} 4\right)$ Experimental design matrix and result.

\begin{tabular}{|c|c|c|c|c|c|c|}
\hline \multirow[t]{2}{*}{ Run } & \multicolumn{4}{|c|}{$\begin{array}{l}\text { Coded Control } \\
\text { Factors }\end{array}$} & \multicolumn{2}{|c|}{$\begin{array}{l}\text { Piperine Yield } \\
\quad(w / w \%)\end{array}$} \\
\hline & $\mathrm{x}_{1}$ & $\mathrm{x}_{2}$ & $\mathrm{x}_{3}$ & $\mathrm{x}_{4}$ & $\left(\mathrm{y}_{\text {black }}\right)$ & ( $\left.\mathrm{y}_{\text {white }}\right)$ \\
\hline 1 & -1 & -1 & -1 & -1 & $\begin{array}{l}1.3972 \\
\pm 0.06\end{array}$ & $\begin{array}{c}0.214 \pm \\
0.02\end{array}$ \\
\hline 2 & -1 & 0 & 0 & 0 & $\begin{array}{c}0.6984 \\
\pm 0.30\end{array}$ & $\begin{array}{c}0.166 \pm \\
0.008\end{array}$ \\
\hline 3 & -1 & +1 & +1 & +1 & $\begin{array}{l}0.7160 \\
\pm 0.62\end{array}$ & $\begin{array}{c}0.258 \pm \\
0.07\end{array}$ \\
\hline 4 & 0 & -1 & 0 & +1 & $\begin{array}{l}1.1944 \\
\pm 0.38\end{array}$ & $\begin{array}{c}0.494 \pm \\
0.008\end{array}$ \\
\hline 5 & 0 & 0 & +1 & -1 & $\begin{array}{c}1.1118 \\
\pm 0.23\end{array}$ & $\begin{array}{c}1.827 \pm \\
0.01\end{array}$ \\
\hline 6 & 0 & +1 & -1 & 0 & $\begin{array}{c}0.8678 \\
\pm 0.02\end{array}$ & $\begin{array}{c}0.616 \pm \\
0.06\end{array}$ \\
\hline 7 & +1 & -1 & +1 & 0 & $\begin{array}{c}0.5862 \\
\pm 0.11\end{array}$ & $\begin{array}{c}0.924 \pm \\
0.04\end{array}$ \\
\hline 8 & +1 & 0 & -1 & +1 & $\begin{array}{c}2.0586 \\
\pm 0.04\end{array}$ & $\begin{array}{c}1.87 \pm 0 . \\
03\end{array}$ \\
\hline 9 & +1 & +1 & 0 & -1 & $\begin{array}{c}0.7668 \\
\pm 0.15\end{array}$ & $\begin{array}{c}4.276 \pm \\
0.02\end{array}$ \\
\hline
\end{tabular}

\section{Validity of the optimized conditions}

The optimal extraction conditions obtained for a maximized Piperine extraction were experimentally validated. A close agreement between the predicted and experimental optimal Piperine yield was estimated using the X-goodness-of-fit-test, as shown in the equation below:

$$
X=\sqrt{\frac{\sum(E-P)}{P}}
$$

The $\mathrm{X}$ goodness-of-fit test was used to examine the validity of the optimum response setting 16 . According to Haldar ${ }^{17}$,for an optimal condition to be valid the X-cut-off mark must not exceed 7.81 for a 3degree of freedom at $95 \%$ confidence level.

The close agreement that existed between the predicted and experimental optimal yield were estimated using the X-goodness-of-fit test ${ }^{16}$. The test shows that there is no significant difference between the predicted and experimental optimum response settings with $\mathrm{X}^{2}$ value of 0.043 and 0.059 for the Piperine yields in black and white pepper respectively as shown in Table 3 . The $X^{2}$ -values are therefore negligible when compared with the 7.81 cut-off value for a 3-degree of freedom. This indicated valid optimal conditions at $95 \%$ confidence leable 3: Validation for optimal condition.

\begin{tabular}{|c|c|c|c|c|c|}
\hline \multirow[t]{2}{*}{ Sample } & \multirow{2}{*}{$\begin{array}{c}\text { Predicted } \\
(\mathrm{w} / \mathrm{w})\end{array}$} & \multicolumn{3}{|c|}{ Observed(w/w) } & \multirow{2}{*}{$\begin{array}{c}\mathrm{X} \\
\text { Goodness } \\
\text { of Fit }\end{array}$} \\
\hline & & $\begin{array}{c}\text { Tria } \\
11\end{array}$ & $\begin{array}{c}\text { Trial } \\
2\end{array}$ & $\begin{array}{c}\text { Trial } \\
3\end{array}$ & \\
\hline $\begin{array}{l}\text { Black } \\
\text { Pepper }\end{array}$ & 2.06 & 2.06 & 1.99 & 2.07 & 0.043 \\
\hline $\begin{array}{l}\text { White } \\
\text { Pepper }\end{array}$ & 4.27 & 4.16 & 4.30 & 4.26 & 0.059 \\
\hline
\end{tabular}

Table 4 shows the scavenging activity dependence on spice oleoresin concentration with an $\mathrm{IC}_{50}$ value of $94.92 \mu \mathrm{g} / \mathrm{mL}$ and $107.57 \mu \mathrm{g} / \mathrm{mL}$ for both black and white oleoresin extracts respectively. This suggests that the DPPH radical scavenging activity of white spice oleoresin extracts is greater than that of the black extracts. This is attributable to the presence of higher concentration of Piperine in white pepper as compare to the black pepper ${ }^{15}$. This is consistent with the investigation carried out by Zhang and $\mathrm{Xu}^{20}$, who concluded that the white ethanolic extracts of white spice oleoresin exhibits an higher scavenging potentials than that of black spice oleoresin.All experimental procedure were performed in triplicates and the one-way statistical analysis (ANOVA) was carried out to determine the coefficient of determination $\left(\mathrm{R}^{2}\right.$-value $)$ and the significant differences between means $(\mathrm{p}<0.05)$ using Minitab17® software.

Table 4: DPPH radical scavenging assay.

\begin{tabular}{|c|c|c|c|c|}
\hline $\begin{array}{l}\text { Sample } \\
\text { Name }\end{array}$ & $\begin{array}{c}\mathrm{IC}_{50} \text { value } \\
(\mu \mathrm{g} / \mathrm{mL})\end{array}$ & $\begin{array}{l}\text { Regression } \\
\text { Equations }\end{array}$ & $\begin{array}{l}\mathrm{R}^{2} \text { - } \\
\text { value }\end{array}$ & $\begin{array}{c}p- \\
\text { value }\end{array}$ \\
\hline $\begin{array}{c}\text { Black } \\
\text { Spice } \\
\text { Oleoresin }\end{array}$ & $\begin{array}{c}107.5667 \\
\pm 0.04\end{array}$ & $\begin{array}{c}I=17.73 c+ \\
0.3000\end{array}$ & 0.85 & 0.01 \\
\hline $\begin{array}{c}\text { White } \\
\text { Spice } \\
\text { Oleoresin }\end{array}$ & $\begin{array}{c}94.9219 \\
\pm 0.01\end{array}$ & $\begin{array}{c}I=18.41 \mathrm{c}+ \\
0.3328\end{array}$ & 0.87 & 0.01 \\
\hline
\end{tabular}

Figure 3 shows the inhibitory plot which illustrated the comparison between the scavenging activities of black and white pepper oleoresin extracts. Deduction made from the graph indicated that the concentration- 


\section{Chemical Engineering Research Bulletin 19(2017) 139-144}

dependent radicals scavenging activity of white oleoresin extract was $11.8 \%$ higher than that of black oleoresin extract. This is conformable with other results from previous investigation ${ }^{2,20}$.

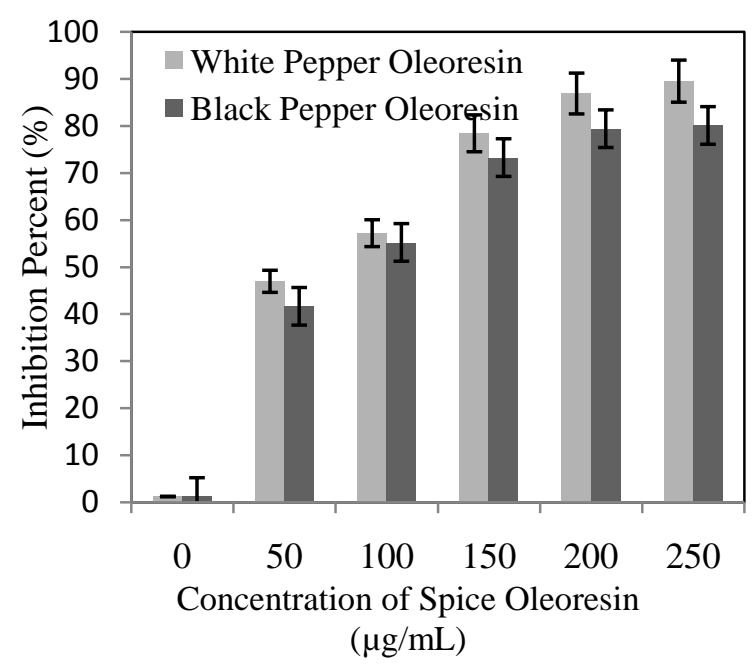

Figure 3: Comparison of inhibitory calibration plot for white and black free radical scavenging assay.

\section{Conclusion}

This study concluded that the white pepper contained a higher proportion of antioxidant than that of black pepper. Moreover, from the estimated $\mathrm{IC}_{50}$ value, it can be clearly seen that the white pepper oleoresin extracts offer a better antioxidant activity than the corresponding black pepper oleoresin extracts. This indicated that allowing an immature flowering plant of piper nigrum to mature increases the Piperine content and hence the radical scavenging ability of its oleoresin extracts. This gives substantial evidence that black and white oleoresin extract can be possibly used as dietary antioxidants for the protection of free radical related diseases.

\section{Acknowledgement}

I wish to acknowledge the financial support and sponsorship from the Doctoral Scholarship Scheme of the Malaysian Ministry of Education (MOE), and the PGRS-160320 research grant from Universiti Malaysia Pahang(UMP),Malaysia.

\section{References}

1. A. Gupta, M. Gupta, and S. Gupta, "Isolation of Piperine and Few Sesquiterpenes from the Cold Petroleum Ether Extract of Piper nigrum ( Black Pepper ) and its Antibacterial Activity,"
International Journal of Pharmacognosy and Phytochemical Research,vol. 5, no. 2, pp. 3-7, 2013.

2. S. Singh, I. P. S. K. Gurdip, and S. Carola, "Chemistry , Antioxidant and Antimicrobial Potentials of White Pepper ( Piper nigrum L .) Essential Oil and Oleoresins,"The National Academy of Sciences, India vol. 83, no. 3, pp. 357-366, 2013.

3. M. Meghwal and G. Tk, "Nutritional Constituent of Black Pepper as Medicinal Molecules: A Review," Open access report, vol. 1, no. 1, pp. 17, 2012.

4. C. Khushbu, R. Article, C. Khushbu, S. Roshni, P. Anar, M. Carol, and P. Mayuree, "Phytochemical and Therapeutic Potential of Piper longum linn: A review,"International Journal of Research in Ayurveda \& Pharmacy, vol. 2, no. 1, pp. 157-161, 2011.

5. Z.Maitreyi, A. Khandhar, S. Patel, A. Patel, "Chemistry and Pharmacological piper nigrum," International Journal of Pharmaceutical Sciences Review and Research,vol.5,no.1,pp. 67-76,2010.

6. W. Epstein, "Isolation of Piperine from Black Pepper."Journal Chemical Education, vol.70, 598599,1993.

7. N. H. Abdurahman, "A Comparative Review Of Conventional And Microwave Assisted Extraction In Capsaicin Isolation From Chili Pepper," Australian Journal of Basic and Applied Science, vol. 10, no. 6, pp. 263-275, 2016.

8. E. Durmaz, G. Sumnu, and S. Sahin, "MicrowaveAssisted Extraction of Phenolic Compounds from Caper," Separation Science. Technology,vol.6395,no.8,2015.

9. M. Mohan, S. Khanam, and B. G. Shivananda, "Optimization of Microwave Assisted Extraction of Andrographolide from Andrographis paniculata and its Comparison with Refluxation Extraction Method,"Journal of Pharmacognosy and Phytochemistry Optimization, vol. 2, no. 1, pp. 342-348, 2013.

10. L. Sanchez-prado, C. Garcia-jares, and T. Dagnac, "Microwave-assisted extraction of emerging pollutants in environmental and biological samples before chromatographic determination," Trends in Analytical Chemistry, 71, pp. 119-143, 2015.

11. V. Mandal, Y. Mohan, and S. Hemalatha, "Microwave assisted extraction of curcumin by sample-solvent dual heating mechanism using Taguchi L9 orthogonal design," Journal of Pharmaceutical and Biomedical Analysis, 46, no. 2, pp. 322-327, 2008.

12. D. M. Steinberg and D. Bursztyn, "Noise Factors, Dispersion Effects, and Robust Design," Statistical. Sinica., vol. 8, pp. 67-85, 1998. 


\section{Chemical Engineering Research Bulletin 19(2017) 139-144}

13. H.Abdurahman,O.Olalere,

"Taguchi-Based Optimization Technique in reflux microwave extraction of piperine from black pepper," Australian Journal of Basic and Applied Sciences, vol. 10, no.5. pp. 293-299, 2016.

14. Minitab, Getting Started with Minitab 17. 2014.

15. S. Singh, I. P. S. Kapoor, G. Singh, C. Schuff, M. P. De Lampasona, and C. A. N. Catalan, "Chemistry, antioxidant and antimicrobial potentials of white pepper (Piper nigrum L.) essential oil and oleoresins," Proceedings of. Nationa. Academy Science India Section B Biological. Sci.ence, vol. 83,2013.

16. E. Subroto, R. Manurung, H. J. Heeres, and A. A. Broekhuis, "Optimization of mechanical oil extraction from Jatropha curcas L. kernel using response surface method," Industrial Crops Product, vol. 63, pp. 294-302, 2015.

17. S. Haldar, G. C. Majumdar, and H. N. Mishra,
"Modeling the kinetics of extracting oleoresin from dried turmeric (Curcuma longa L.) rhizome using acetone as solvent," Journal of Food Engineering., vol. 146, no.11, pp. 116-121, 2015.

18. L. S. Badwaik, P. K. Borah, and S. C. Deka, "Optimization of Microwave Assisted Extraction of Antioxidant Extract from Garcinia pedunculata Robx.," Separation Science. Technology., vol. 50, no. 12, pp. 1814-1822, 2015.

19. G. Nahak and R. K. Sahu, "Phytochemical Evaluation and Antioxidant activity of Piper cubeba and Piper nigrum," Journal of Applied Pharmaceutical Sciencevol. 1, no. 8, pp. 153-157, 2011.

20. L.L Zhang and J.G. Xu, "Comparative Study on Antioxidant Activity of Essential Oil,"European Journal of Food Science and Technology vol. 3, no. 3, pp. 10-16, 2015.

\section{Available online at http://www.banglajol.info/index.php/CERB}

Publisher: Department of Chemical Engineering, Bangladesh University of Engineering and Technology (BUET). Review \&Publication: A submitted original manuscript is taken into review only if the uniqueness is found to be more than $85 \%$ in plag-scanning and selected for publication by the complete acceptance from at least two reviewers out of three. Home Page: http://www.banglajol.info/index.php/CERB . Indexed by Chemical Abstract Service (CAS), CEABA-VtB, Google Scholar, Scopus and DOAJ. 